2015

\title{
What Do the National Data Tell Us About Minority Teacher Shortages?
}

Richard Ingersoll

University of Pennsylvania, rmi@upenn.edu

Follow this and additional works at: https://repository.upenn.edu/gse_pubs

Part of the Education Commons

\section{Recommended Citation}

Ingersoll, R. (2015). What Do the National Data Tell Us About Minority Teacher Shortages?. The State of Teacher Diversity in American Education, 13-22. Retrieved from https://repository.upenn.edu/gse_pubs/541

This paper is posted at ScholarlyCommons. https://repository.upenn.edu/gse_pubs/541

For more information, please contact repository@pobox.upenn.edu. 


\title{
What Do the National Data Tell Us About Minority Teacher Shortages?
}

\begin{abstract}
For the past several decades, shortages of minority teachers have been a big issue for the nation's schools. Policymakers at all levels, including recent presidents, have agreed that our elementary and secondary teaching force "should look like America." But conventional wisdom is that as the nation's population and students have grown more racially and ethnically diverse, the teaching force has done the opposite. The result, we are told, is that minority students in the nation's schools increasingly lack minority adult role models, don't have sufficient contact with teachers who understand their racial and cultural backgrounds, and often lack qualified teachers of any background, because nonminority teachers eschew schools with large percentages of minorities. The minority teacher shortage in turn, we are told, is a major reason for the minority achievement gap and, ultimately, unequal occupational and life outcomes for disadvantaged students. In short, the minority teacher shortage is considered a major civil rights issue (for reviews, see Quiocho \& Rios, 2000; Torres et al., 2004; Villegas \& Lucas, 2004; Zumwalt \& Craig, 2005).
\end{abstract}

The main source of minority teacher shortages, conventional wisdom holds, is a problem with the teacher supply pipeline. In this view, too few minority students enter and complete college, and those who do have an increasing number of career and employment options aside from teaching. Moreover, when minority candidates do seek to enter teaching, this view holds, they encounter barriers-in particular, teaching entry tests, on which minority candidates historically have tended to have lower pass rates. The result is the minority teacher shortage.

The prescription, understandably enough, has been to try to recruit more minority candidates into teaching. In recent decades, numerous government and nongovernment organizations have launched a variety of minority teacher recruitment programs and initiatives, including future educator programs in high schools, partnerships between community colleges and four-year teacher education programs, career ladders for paraprofessionals in schools, and alternative teacher certification programs (see, e.g., Hirsch, Koppich \& Knapp, 2001; Feistritzer, 1997; Liu et al., 2008; Rice, Roellke, Sparks \& Kolbe, 2008). Support for these efforts has been substantial. For instance, beginning in the late 1980s, the Ford Foundation, along with the DeWitt Wallace Reader's Digest Fund, committed more than $\$ 60$ million to minority teacher recruitment and preparation programs. Many of these initiatives have been designed to bring minority teachers into schools serving predominantly minority student populations, often in low-income, urban school districts. Some of these initiatives have been designed specifically to recruit minority men, as they are often considered to be in the shortest supply. Today, in more than half of the states, minority teacher recruitment policies or programs of some sort are in place. Despite these ongoing efforts, however, many commentators see little success, claiming that, if anything, the student-teacher diversity gap has widened (e.g., Villegas, Strom and Lucas, 2012). This raises important questions: Has the teaching force grown more diverse or less so? And if diversity has not increased, why haven't these efforts been successful? This section seeks to address these questions.

\section{Disciplines \\ Education}




\section{The State OF}

\section{TEACHER DIVERSITY}

IN AMERICAN EDUCATION

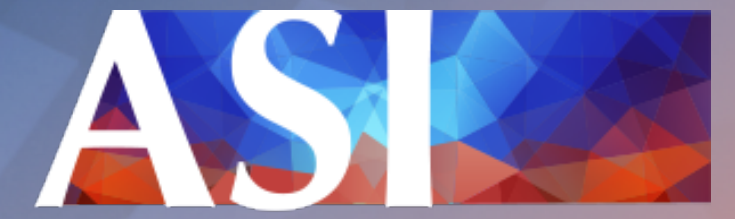




\section{SECTION III:}

\section{What Do the National Data Tell Us About Minority Teacher Shortages?}

\section{By Richard Ingersoll, University of Pennsylvania}

\section{INTRODUCTION}

For the past several decades, shortages of minority teachers have been a big issue for the nation's schools. Policymakers at all levels, including recent presidents, have agreed that our elementary and secondary teaching force "should look like America." But conventional wisdom is that as the nation's population and students have grown more racially and ethnically diverse, the teaching force has done the opposite. The result, we are told, is that minority students in the nation's schools increasingly lack minority adult role models, don't have sufficient contact with teachers who understand their racial and cultural backgrounds, and often lack qualified teachers of any background, because nonminority teachers eschew schools with large percentages of minorities. The minority teacher shortage in turn, we are told, is a major reason for the minority achievement gap and, ultimately, unequal occupational and life outcomes for disadvantaged students. In short, the minority teacher shortage is considered a major civil rights issue (for reviews, see Quiocho \& Rios, 2000; Torres et al., 2004; Villegas \& Lucas, 2004; Zumwalt \& Craig, 2005).

The main source of minority teacher shortages, conventional wisdom holds, is a problem with the teacher supply pipeline. In this view, too few minority students enter and complete college, and those who do have an increasing number of career and employment options aside from teaching. Moreover, when minority candidates do seek to enter teaching, this view holds, they encounter barriers-in particular, teaching entry tests, on which minority candidates historically have tended to have lower pass rates. The result is the minority teacher shortage.

The prescription, understandably enough, has been to try to recruit more minority candidates into teaching. In recent decades, numerous government and nongovernment organizations have launched a variety of minority teacher recruitment programs and initiatives, including future educator programs in high schools, partnerships between community colleges and four-year teacher education programs, career ladders for paraprofessionals in schools, and alternative teacher certification programs (see, e.g., Hirsch, Koppich \& Knapp, 2001; Feistritzer, 1997; Liu et al., 2008; Rice, Roellke, Sparks \& Kolbe, 2008). Support for these efforts has been substantial. For instance, beginning in the late 1980s, the Ford Foundation, along with the DeWitt Wallace Reader's Digest Fund, committed more than $\$ 60$ million to minority teacher recruitment and preparation programs. Many of these initiatives have been designed to bring minority teachers into schools serving predominantly minority student populations, often in low-income, urban school districts. Some of these initiatives have been designed specifically to recruit minority men, as they are often considered to be in the shortest supply. Today, in more than half of the states, minority teacher recruitment policies or programs of some sort are in place. Despite these ongoing efforts, however, many commentators see little success, claiming that, if anything, the student-teacher diversity gap has widened (e.g., Villegas, Strom and Lucas, 2012). This raises important questions: Has the teaching force grown more diverse or less so? And if diversity has not increased, why haven't these efforts been successful? This section seeks to address these questions.

This section draws from and updates an earlier study, undertaken with Henry May, that analyzed two decades of national data from the late 1980s to 2009 on minority teacher recruitment, retention and shortages (for reports of this earlier study, see Ingersoll \& May, 2011a; Ingersoll \& May, 2011b). 


\section{THE STUDY}

This section summarizes a study I recently completed that used the best national data available in an attempt to empirically ground the debate on the recruitment, employment and retention of minority teachers.

Our study sought to address several questions:

- The Number of Minority Teachers: Has the number of minority teachers been going up or down in recent decades? What changes have there been, if any, in the number of minority students and teachers, and how does this compare with nonminority students and teachers?

- The Employment of Minority Teachers: Where are minority teachers employed? Are minority teachers more likely than nonminority teachers to be employed in schools serving high-poverty, high-minority, urban student populations?

- Minority Teacher Turnover: How does minority teacher retention compare with that of nonminority teachers, and has it been going up or down?

- What Can Be Done to Increase the Number of Minority Teachers? What are the implications of the data for the prospects of increasing the number of minority teachers?

Note that this section focuses on changes in the employment and retention of minority teachers, and does not focus on the important and contentious question of whether minority teachers are better at teaching minority students.

The data we analyzed for this study are from the nationally representative Schools and Staffing Survey (SASS) and its longitudinal supplement, the Teacher Follow-Up Survey (TFS), both administered by the National Center for Education Statistics in the U.S. Department of Education. SASS is the largest and most comprehensive data source available on teachers. There have been seven SASS cycles to date: 1987-88, 1990-91, 1993-94, 1999-00, 2003-04, 2007-08 and 2011-12. Twelve months after the administration of SASS, the same schools are contacted again, and all those in the original teacher sample who had departed from their schools are given a second questionnaire to obtain information on their departures. The TFS comprises this latter group, along with a representative sample of those who stayed in their teaching jobs (for information on SASS and TFS, see NCES, 2005). Our analyses use data from all seven cycles of SASS and TFS, covering the 25-year period from 1987 to 2013.

Throughout this study, the definitions of minority teachers and nonminority teachers are based on Census Bureau classifications of race/ethnicity. Nonminority refers to those identified as White, non-Hispanic. Minority includes those identified as Black/African-American, Hispanic, Native Hawaiian/Pacific Islander or Asian, and American Indian/Native American/Alaska Native, and those of multiple races. Hispanic refers to ethnicity and includes those of all races; it is important to recognize that more than half of those identifying as Hispanic are White. Hence, the term person of color is not synonymous with minority; hence, for clarity, we will not use the former term.

\section{THE RESULTS}

\section{The Number of Minority Teachers}

The data clearly show that there continues to be a persistent racial-ethnic parity gap between the percentage of minority students and the percentage of minority teachers in the U.S. school system. For instance, in the 2011-12 school year, 37 percent of the nation's population was minority and 44.1 percent of all elementary and secondary students were minority, but only 17.3 percent of all elementary and secondary teachers were minority (see Table NAT-1). This student-teacher gap also exists for each of the major minority subgroups, as illustrated in Table NAT-2. For example, in 2011-12, while 21 percent of elementary and secondary students in the United States were Hispanic, only 7.5 percent of teachers were Hispanic. 
TABLE NAT-1: TRENDS IN THE NATION'S POPULATION, K-12 STUDENT ENROLLMENT AND THE K-12 TEACHING FORCE, BY RACE AND ETHNICITY, 1987-2012

\begin{tabular}{|c|c|c|c|c|c|c|c|c|}
\hline & $\begin{array}{r}1987-88 \\
\text { School Year }\end{array}$ & $\begin{array}{r}1990-91 \\
\text { School Year }\end{array}$ & $\begin{array}{r}1993-94 \\
\text { School Year }\end{array}$ & $\begin{array}{r}1999-00 \\
\text { School Year }\end{array}$ & $\begin{array}{r}2003-04 \\
\text { School Year }\end{array}$ & $\begin{array}{r}2007-08 \\
\text { School Year }\end{array}$ & $\begin{array}{r}2011-12 \\
\text { School Year }\end{array}$ & $\begin{array}{r}\% \text { Increase, } \\
1987-88 \text { to } \\
2011-12 \\
\end{array}$ \\
\hline Percent Minority Population of U.S. & 23.1 & 24.3 & 25.6 & 28.1 & 32.1 & 34.4 & 37.0 & \\
\hline Total Student Enrollment & $45,220,953$ & $44,777,577$ & $46,592,207$ & $50,629,075$ & $52,375,110$ & $53,644,872$ & $53,988,330$ & 19 \\
\hline Number White, non-Hispanic Students & $31,641,098$ & $31,213,142$ & $31,895,394$ & $32,700,441$ & $32,419,640$ & $31,864,127$ & $30,164,827$ & -5 \\
\hline Number Minority Students & $12,335,372$ & $13,564,435$ & $14,696,813$ & $17,928,634$ & $19,955,470$ & $21,780,745$ & $23,825,612$ & 93 \\
\hline Percent Minority Students & 27.3 & 30.3 & 31.5 & 35.4 & 38.1 & 40.6 & 44.1 & \\
\hline Total Teaching Force & $2,630,335$ & $2,915,774$ & $2,939,659$ & $3,451,316$ & $3,717,998$ & $3,894,065$ & $3,850,058$ & 46 \\
\hline Number White, non-Hispanic Teachers & $2,303,094$ & $2,542,720$ & $2,564,416$ & $2,933,591$ & $3,113,249$ & $3,252,234$ & $3,183,837$ & 38 \\
\hline Number Minority Teachers & 327,241 & 373,054 & 375,243 & 517,725 & 604,749 & 641,830 & 666,221 & 104 \\
\hline Percent Minority Teachers & 12.4 & 12.8 & 12.8 & 15.0 & 16.3 & 16.5 & 17.3 & \\
\hline
\end{tabular}

TABLE NAT-2: PERCENTAGE OF STUDENTS AND TEACHERS, BY RACE AND ETHNICITY, $2011-2012$

\begin{tabular}{lrrrrrrr}
\hline & $\begin{array}{r}\text { White, non- } \\
\text { Hispanic }\end{array}$ & Minority & Black & Hispanic & Asian & $\begin{array}{r}\text { American } \\
\text { Indian }\end{array}$ & $\begin{array}{r}\text { Multiple } \\
\text { Races }\end{array}$ \\
\hline Students & 55.9 & 44.1 & 14.4 & 21.1 & 5.1 & 1.2 & 2.3 \\
Teachers & 82.7 & 17.3 & 6.4 & 7.5 & 1.9 & 0.4 & 1.0 \\
\hline \hline
\end{tabular}

But the data also show that this student-teacher parity gap has persisted in recent years largely because the number of nonminority students has decreased while the number of minority students has increased (Table NAT-1). The gap is not due to a failure to recruit minority teachers.

Since the late 1980s, the number of elementary and secondary teachers has dramatically increased. This is especially true for minority teachers, whose numbers have more than doubled from about 325,000 to 666,000. Even as the size of the teaching force has grown, the percentage of minority teachers has increased steadily-from 12 to 17 percent (bottom row of Table NAT-1). Growth in the number of minority teachers outpaced growth in the number of minority students and was more than twice the growth rate of nonminority teachers during this 24year period (see Figure NAT-1). So, while there is still not parity between the proportions of minority students and minority teachers in schools, the U.S. teaching force has grown more diverse since the late 1980s. 


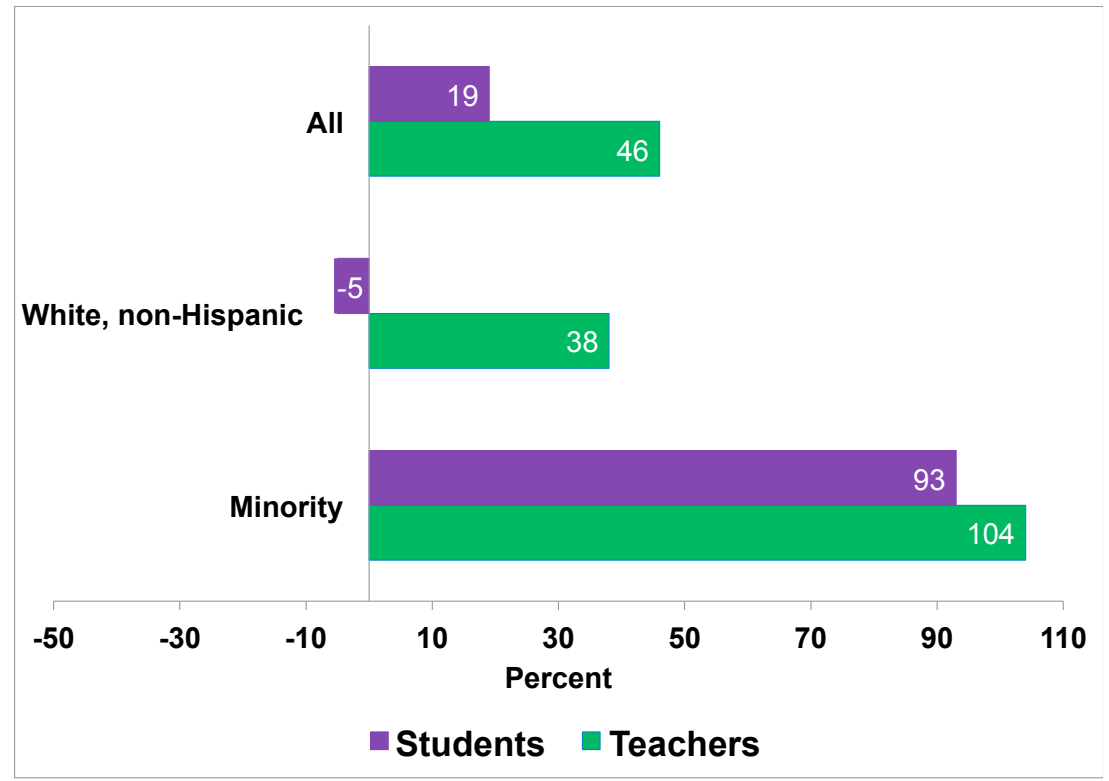

Interestingly, the overall growth pattern from 1987 to 2012 was also true for male minority teachers. Teaching has long been a predominantly female occupation, and in recent decades, it has become increasingly so (Ingersoll, Merrill \& Stuckey, 2014). But this varies by race and ethnicity. Over the two and a half decade period from 1987 to 2012, the number of nonminority male teachers increased by only 12 percent, but the number of minority male teachers increased by 109 percent. In 2011-12, males represented about 24 percent of all nonminority teachers and about 25 percent of all minority teachers.

However, the overall growth from 1987 to 2012 in the number of minority teachers also greatly varied across different minority subgroups and across different time periods. This is shown in Figures NAT-2 and NAT-3, which disaggregate the data in Figure NAT-1, by both group and time.

FIGURE NAT-2: PERCENT CHANGE IN STUDENTS AND TEACHERS, BY RACE AND ETHNICITY, 1987-88 TO $2007=08$

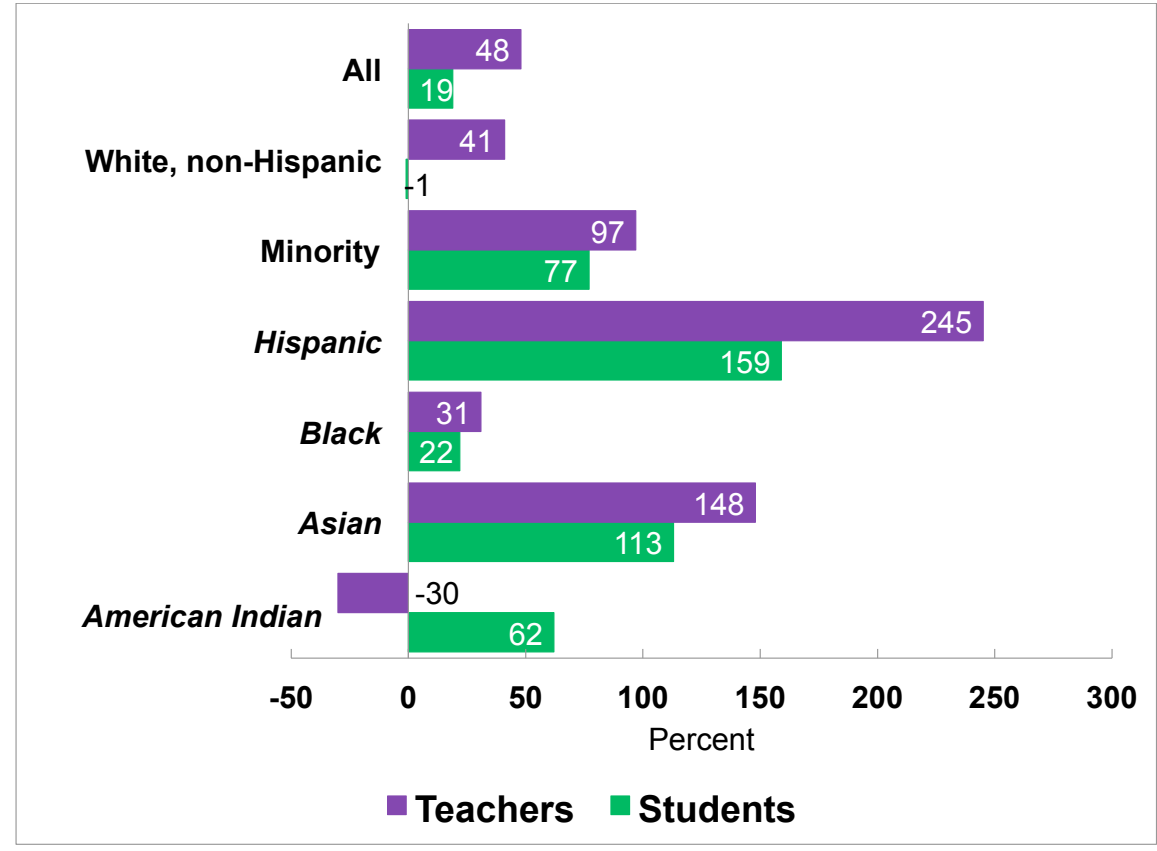




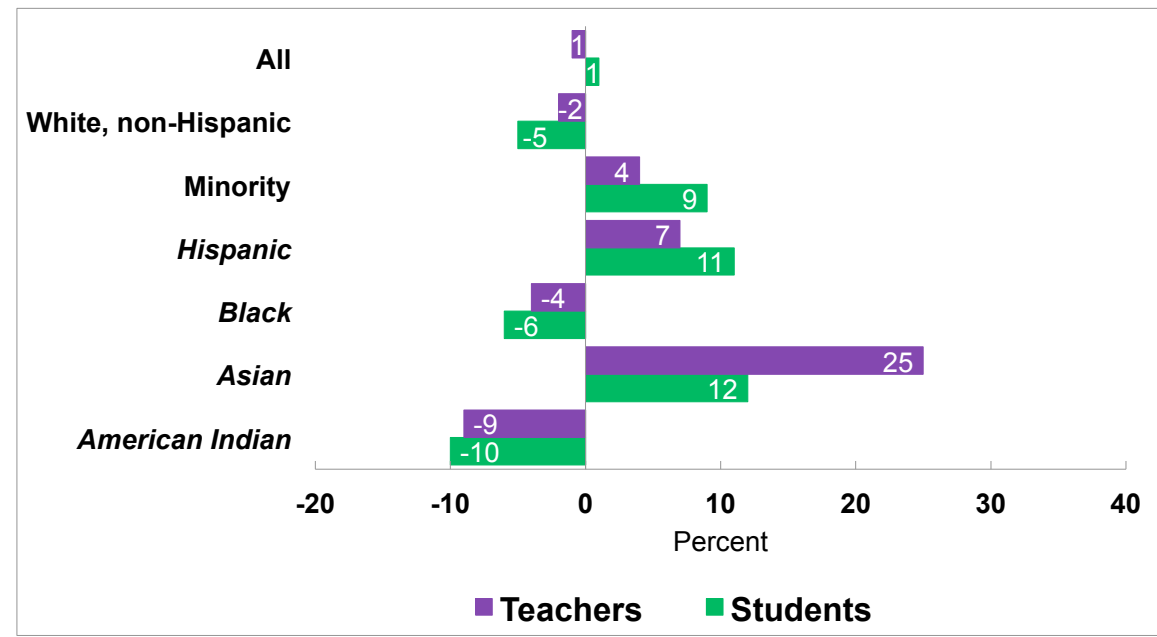

During the period from 1987 to 2008, the overall number of both teachers and students increased. Moreover, in all but one case, growth in minority teachers outpaced growth in minority students (see Figure NAT-2). While the number of nonminority teachers increased by 41 percent, the number of Hispanic teachers increased by 245 percent and the number of Asian teachers increased by 148 percent. Black teachers also grew in number, but at a far slower rate. The large exception to this growth was American Indian teachers, who declined in number by 30 percent. American Indians comprise only 1 percent of students and less than half a percent of the teaching force.

This pattern changed after 2008, when the economic downturn and recession began. Figure NAT-3 shows trends for the period from 2008 to 2012. During that period, there was a decline in the number of nonminorities, Blacks and American Indians, for both teachers and students. In contrast, the number of Hispanic and Asian teachers and students continued to increase.

\section{The Employment of Minority Teachers}

While there has been a dramatic increase in minority teachers, this growth has not been equally distributed across different types of schools. In 2011-12, 92 percent of minority teachers were employed in public schools (Table NAT3). Moreover, minority teachers were overwhelmingly employed in public schools serving high-poverty, high-minority, urban communities. Nearly two-thirds of minority teachers worked in schools serving predominantly minority students. A similar proportion was employed in high-poverty schools. Minority teachers were two to three times more likely than nonminority teachers to work in such hard-to-staff schools. In contrast, only 3 percent of minority teachers were in low-minority schools (i.e., those in which less than a 10th of the students are minority). 
TABLE NAT-3: OF MINORITY AND WHITE, NON-HISPANIC SCHOOL TEACHERS, PERCENTAGE EMPLOYED IN DIFFERENT TYPES OF SCHOOLS, 2011-2012

\begin{tabular}{|c|c|c|c|c|c|c|c|}
\hline School Type & $\begin{array}{r}\text { White, non- } \\
\text { Hispanic }\end{array}$ & Minority & Black & Hispanic & Asian & $\begin{array}{r}\text { American } \\
\text { Indian } \\
\end{array}$ & $\begin{array}{r}\text { Multiple } \\
\text { Races }\end{array}$ \\
\hline Public & 87.1 & 91.9 & 93.2 & 91.5 & 87.5 & 97.6 & 91.5 \\
\hline Urban & 25 & 45 & 50 & 44 & 49 & 19 & 33 \\
\hline Suburban & 33 & 29 & 27 & 32 & 28 & 20 & 38 \\
\hline High Poverty & 31 & 62 & 68 & 63 & 52 & 59 & 42 \\
\hline Low Poverty & 23 & 11 & 8 & 11 & 18 & 7 & 21 \\
\hline High Minority & 21 & 64 & 67 & 67 & 59 & 43 & 41 \\
\hline Low Minority & 21 & 3 & 1 & 3 & 5 & 5 & 8 \\
\hline Private & 12.9 & 8.1 & 6.8 & 8.5 & 12.5 & 2.4 & 8.5 \\
\hline
\end{tabular}

Note: High-poverty schools are those in which $60 \%$ or more of the students are eligible for the federal free or reduced-price lunch program for students from families below poverty level. Low-poverty schools are those in which less than $20 \%$ of the students are eligible for the federal free or reduced-price lunch program. High-minority schools are those in which $75 \%$ or more of the students are minority. Low-minority schools are those in which less than $10 \%$ of the students are minority.

Because minority teachers represented only 17.3 percent of the teaching force in 2011-12, in the types of schools where minority teachers were disproportionately employed, the teaching staff overall was nevertheless predominantly White, non-Hispanic. Figure NAT-4 illustrates this continuing lack of demographic parity. For instance, in high-minority public schools (i.e., those with 75 percent or more minority students), only 40 percent of teachers were minority. Likewise, in high-poverty public schools, only 31 percent of teachers were minority.

FIGURE NAT-4: OF DIFFERENT TYPES OF PUBLIC SCHOOLS, RACE AND ETHNICITY OF THEIR TEACHING STAFFS, 2011-2012

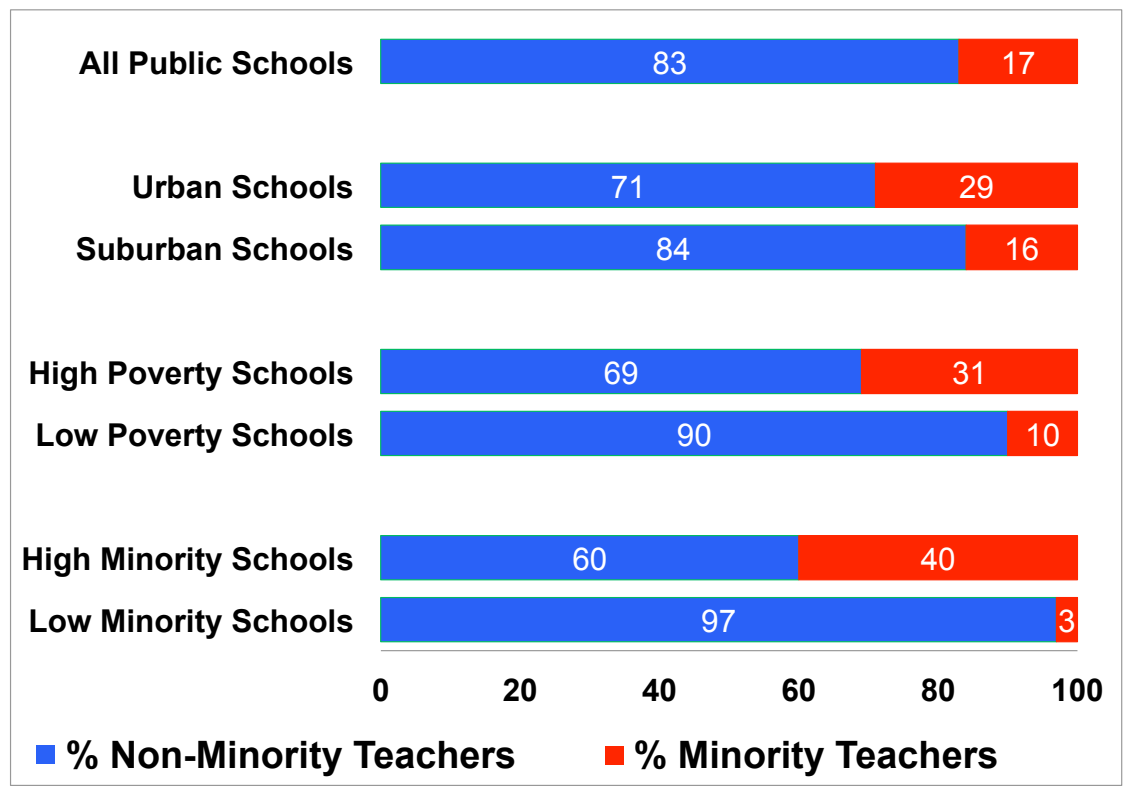

In sum, while a large student-teacher racial and ethnic parity gap persists in schools, the data show that efforts over recent decades to recruit more minority teachers and place them in schools serving disadvantaged and minority students have been very successful. This has been somewhat of an unheralded victory. While commentators and researchers have tended to discuss the minority teacher shortage in dire and pessimistic terms, the data suggest that such efforts and expenditures are working. 


\section{Minority Teacher Turnover}

While minorities entered teaching at higher rates than nonminorities over the two and a half decades from 1987 to 2012, minority teachers also left schools at higher rates. Overall, the data show that minority teachers' careers have been less stable than those of nonminority teachers, and have included more job transitioning. In recent years, minority teachers were more likely to depart their schools, either to migrate to another school or to leave teaching altogether (see Figure NAT-5). This was especially true for male minority teachers.

FIGURE NAT-5: PERCENT OF ANNUAL PUBLIC SCHOOL TEACHER TURNOVER, BY RACE AND ETHNICITY OF TEACHERS, BY YEAR

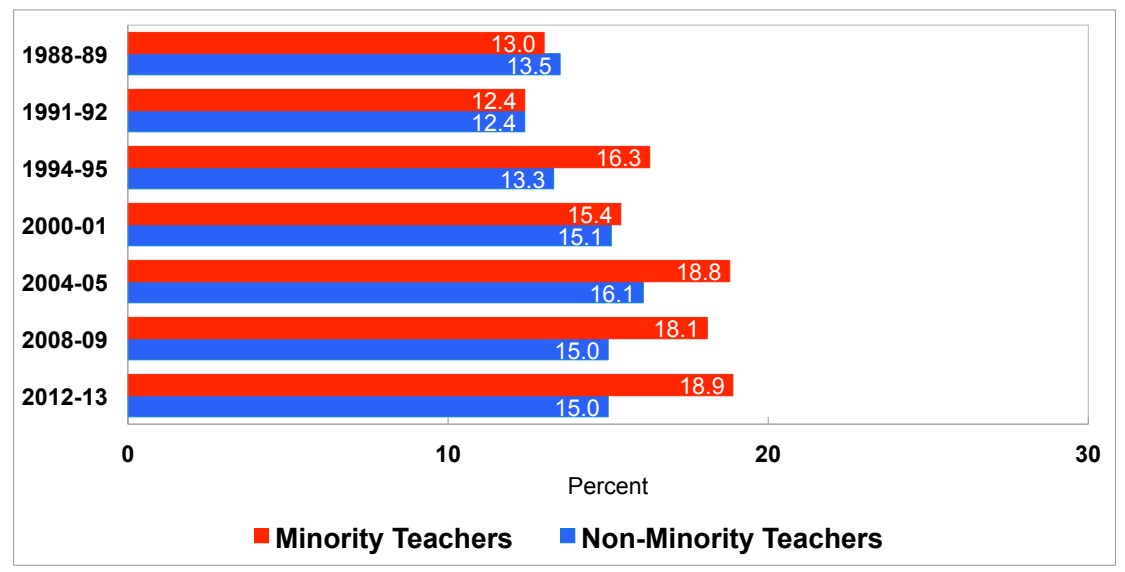

Some turnover and departures of teachers is normal, inevitable and even beneficial. For individuals, departures that lead to better jobs, in teaching or not, are a source of upward mobility. For schools, departures of low-performing employees can enhance school performance. For the educational system as a whole, some teacher career changes-such as moving from one school to another, or leaving classroom teaching for other education-related jobs-do not represent a net loss of human capital.

However, from the viewpoint of those managing schools and those seeking to employ more minority teachers in school classrooms, none of these types of departures are cost-free. All have the same effect: They reduce the number of minority teachers in the organization. One consequence of such turnover, our analysis reveals, is that it undermines efforts to address the minority teacher shortage. For instance, at the beginning of the 2003-04 school year, about 47,600 minority teachers entered teaching; however, by the following school year, 20 percent more-about 56,000-had left teaching. These data convey an image of a revolving door: too many going in one door and out another.

What are the reasons for the high rates of minority teacher turnover? Contrary to conventional wisdom, retirement is not an especially prominent factor (see Figure NAT-6), as it was reported by only 17 percent of those who departed. At 25 percent, school staffing cutbacks due to layoffs, terminations, school closings and reorganizations account for a larger proportion of turnover than does retirement. These staffing actions more often result in teachers migrating to other teaching jobs than leaving the teaching occupation altogether. 
FIGURE NAT-6: PERCENT OF MINORITY PUBLIC SCHOOL TEACHERS REPORTING GENERAL TYPES OF REASONS FOR THEIR TURNOVER, 2012-2013

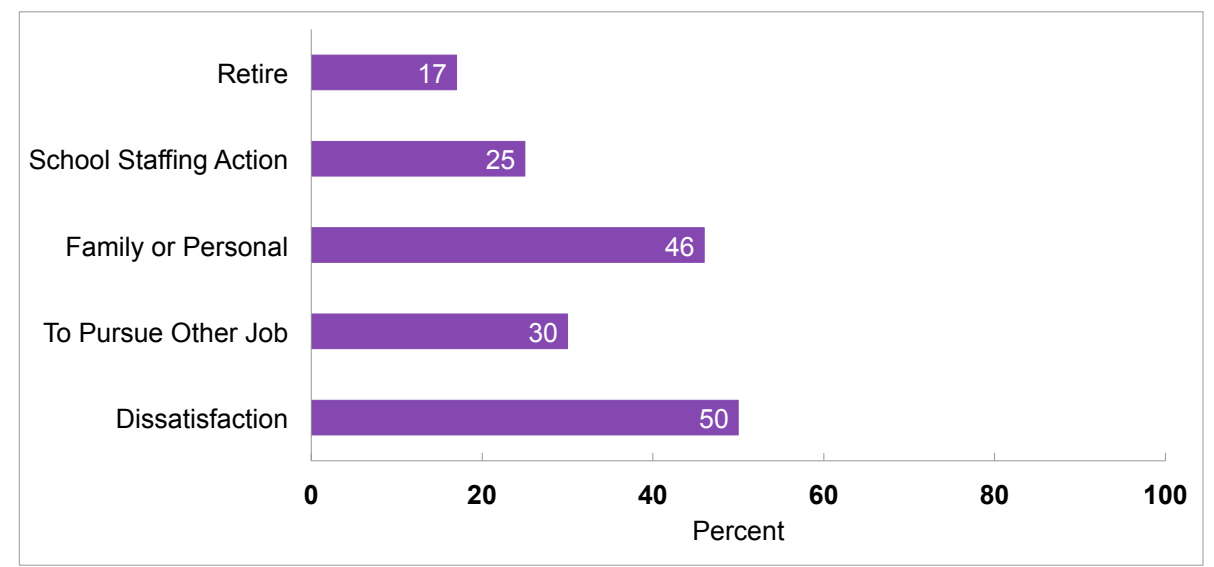

A third category of minority teacher turnover-personal reasons-includes departures for pregnancy, child rearing, health problems and family moves. These account for more turnover than either retirement or staffing actions, and they are probably common to all occupations and all types of organizations. The two final sets of reasons are directly related to the working conditions of teaching. More than half of all those who depart report as a reason either job dissatisfaction or the desire to pursue a better job, another career or better career opportunities in or out of education. Individually, each of these categories accounts for more turnover than does retirement; together, they are the most prominent source of turnover.

Of those minority teachers who depart because of job dissatisfaction, most link their turnover to the way their school is administered, to how student assessments and school accountability affected teaching, to student discipline problems, and to a lack of input into decisions and a lack of classroom autonomy over their teaching (see Figure NAT-7). The data also show that nonminority teachers report similar reasons behind their turnover, and, in general, similar kinds of dissatisfactions underlie both teacher migration and teacher attrition.

FIGURE NAT-7: OF THOSE MINORITY PUBLIC SCHOOL TEACHERS REPORTING DISSATISFACTION, PERCENT REPORTING PARTICULAR REASONS FOR THEIR TURNOVER, 2012-2013

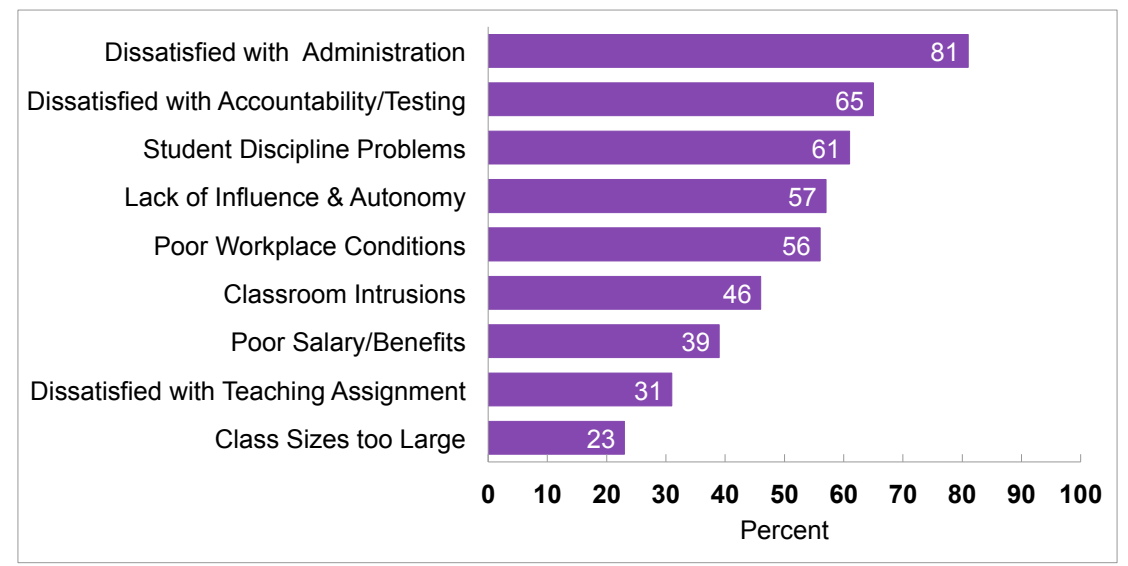

In sum, the data indicate that minority teachers depart their jobs for a variety of reasons. Retirement accounts for a relatively small number of total departures. Some departures are due to school staffing actions, a large proportion of departures is for personal reasons, and another large proportion is for job dissatisfaction or to seek better jobs or other career opportunities. These findings are important because of their policy implications. Unlike explanations that focus on external demographic trends, these findings suggest there is a role for the internal organization and management of schools. 
This brings us to a critical question: Why do minority teachers depart schools at higher rates than do nonminority teachers? Strikingly, while the demographic characteristics of schools appear to be highly important to minority teachers' initial employment decisions, this doesn't appear to be the case for their later decisions about whether to depart. Using advanced statistical analyses (Ingersoll \& May, 2011a), we found that none of the following was strongly or consistently related to the likelihood of minority teachers staying or departing: student poverty levels, proportion of minority students or teachers, or urban or suburban location. According to a companion study, this also appears to be true when analyzing only the data for Black teachers (Connor, 2011).

What does matter is working conditions. While students' race and ethnicity, poverty levels and school urbanicity are not factors in and of themselves, the same hard-to-staff, high-poverty urban schools that are more likely to employ minority teachers are also more likely to have less-desirable working conditions. And these less-desirable conditions, our data suggest, account for the higher rates of minority teacher turnover (see Ingersoll \& May, 2011a). In other words, the data indicate that minority teachers are employed at higher rates in schools serving disadvantaged students, and then depart at higher rates because these same schools tend to be less desirable as workplaces. The tragedy is that the success of minority teacher recruitment efforts has been undermined.

Even more striking was what we found when we looked at which conditions were most correlated with minority teachers' departures. Salary levels, the provision of useful professional development and the availability of classroom resources all had some impact on whether these teachers were likely to leave. However, the strongest factors by far for minority teachers were the level of collective faculty decision-making influence in the school and the degree of individual instructional autonomy held by teachers in their classrooms. Influence and autonomy, of course, are hallmarks of respected professions. Schools that provided teachers with more classroom discretion and autonomy, as well as schools with higher levels of faculty input into school decision making, had significantly lower levels of minority teacher turnover.

\section{What Can Be Done to Increase the Number of Minority Teachers?}

In supply and demand theory, any imbalance between labor demand and supply can be referred to as a shortage, in the sense that too few individuals are able and willing to offer their services under given wages and conditions. From this perspective, the problems encountered by many schools in retaining minority teachers can technically be referred to as a shortage. However, in the context of minority teachers and schools, the term shortage is typically given a narrower connotation-an insufficient production and recruitment of new minority teaching candidates in the face of increasing minority student enrollments. These differences in terminology and diagnosis have crucial implications for prescription and policy.

Increasing production and recruitment of new teachers has long been the dominant strategy for diversifying the teaching force and addressing the minority teacher shortage. And, nothing in our research suggests that bringing new, qualified minority candidates into teaching is not worthwhile. Indeed, our data show that this approach has had remarkable success. In the two and a half decades since the late 1980s, the minority teaching force has increased at more than two and a half times the rate of the nonminority teaching force.

But recruitment alone has not solved the problem of minority teacher shortages or the problem of filling positions in hard-to-staff schools. The data indicate that teacher recruitment strategies alone do not directly address a major source of minority teacher staffing problems-turnover. This is especially true for minority teacher recruitment efforts aimed at male teachers, who have especially high turnover. Indeed, the dramatic growth in the number of minority teachers is all the more remarkable because it has occurred in spite of the high turnover rate among minority teachers.

Improving the retention of minority teachers recruited into teaching, by addressing the factors that drive them out, could prevent the loss of recruitment resources invested and also lessen the need for more recruitment initiatives. These data, and the examples in other sections, suggest the importance of jointly developing teacher recruitment and teacher retention initiatives. In plain terms, it makes no sense to put substantial effort into recruiting minority candidates to teach in schools serving disadvantaged students, if large numbers of those same teachers then leave those schools in a few years. 


\section{REFERENCES}

Connor, R. (2011). Examining African American teacher turnover, past $\mathcal{E}$ present. (PhD. dissertation). University of Pennsylvania, Philadelphia, PA.

Feistritzer, E. (1997). Alternative teacher certification: A state-by-state analysis (1997). Washington, DC: National Center for Education Information.

Hirsch, E., Koppich, J., \& Knapp, M. (2001). Revisiting what states are doing to improve the quality of teaching: An update on patterns and trends. Seattle, WA: Center for the Study of Teaching and Policy, University of Washington.

Ingersoll, R. \& May, H. (2011a). Recruitment, retention, and the minority teacher shortage. Philadelphia, PA: Consortium for Policy Research in Education, University of Pennsylvania and Center for Educational Research in the Interest of Underserved Students, University of California, Santa Cruz.

Ingersoll, R. \& May, H. (2011b). “The Minority Teacher Shortage: Fact or Fable?” Phi Delta Kappan, 93(1) 62-65, (Sept. 2011).

Ingersoll, R. Merrill, L \& Stuckey, D. (2014). Seven Trends: The Transformation of the Teaching Force. CPRE Working Paper (\#RR-80). Philadelphia: Consortium for Policy Research in Education, University of Pennsylvania. (April, 2014 Update)

Liu, E., Rosenstein, J., Swann, A., \& Khalil, D. (2008). When districts encounter teacher shortages: The challenges of recruiting and retaining math teachers in urban districts. Leadership and Policy in Schools, 7(3), 296-323.

National Center for Education Statistics. (2005). Schools and staffing survey (SASS) and teacher follow-up survey (TFS). Data File. Washington, DC: U.S. Department of Education. Available from http://nces.ed.gov/surveys/ SASS

Quiocho, A. \& Rios, F. (2000). The power of their presence: Minority group teachers and schooling. Review of Educational Research, 70(4), 485-528.

Rice, J., Roellke, C., Sparks, D., \& Kolbe, T. (2008). Piecing together the teacher policy landscape: A policy-problem typology. Teachers College Record. Available from http://www.tcrecord.org/Content.asp?ContentId=15223

Torres, J., Santos, J., Peck, N. L., \& Cortes, L. (2004). Minority teacher recruitment, development, and retention. Providence, RI: Brown University, Educational Alliance.

Villegas, A.M. \& Lucas, T. (2004). Diversifying the teacher workforce: A retrospective and prospective analysis. In M.A. Smylie \& D. Miretky (Eds.), Developing the teacher workforce (103rd Yearbook of the National Society for the Study of Education, Part 1) (pp. 70-104). Chicago, IL: University of Chicago Press.

Villegas, A.M., Strom, K. and Lucas, T. 2012. Closing the Racial/Ethnic Gap Between Students of Color and Their Teachers: An Elusive Goal. Equity \& Excellence in Education. 45:2, 283-301.

Zumwalt, K., \& Craig, E. (2005). Teachers' characteristics: Research on the demographic profile. In M. Cochran-Smith \& K.M. Zeichner (Eds.), Studying teacher education: The report of the AERA panel on research and teacher education (pp. 111-156). Mahwah, NJ: Lawrence Erlbaum. 